\title{
Ocorrência de Circovírus suíno tipo 2 em suínos abatidos no Estado do Mato Grosso
}

\author{
Occurrence of Porcine Circuvirus type 2 in slaughtered pigs in state of Mato Grosso \\ João Xavier de Oliveira Filho, Cristiane Silva Chitarra, \\ Daphine Ariadne Jesus de Paula, Isabela de Godoy, Maria Cristina da Silva, \\ Edson Moleta Colodel, Valéria Dutra \& Luciano Nakazato
}

\begin{abstract}
RESUMO
Devido à deficiência de dados sobre a prevalência da infecção em suínos pelo Circovírus suíno tipo 2 (PCV-2) no Brasil e no mundo, e do impacto econômico no sistema de produção de suínos, este trabalho teve como objetivo estimar a ocorrência do PCV-2 em suínos abatidos no Estado do Mato Grosso. Para isso, foi realizada a técnica da Reação em Cadeia da Polimerase (PCR), em que foram avaliadas 121 tonsilas e 147 linfonodos mesentéricos de suínos abatidos no estado durante o período de janeiro de 2006 a dezembro de 2007. De todas as amostras analisadas, 58,21\% (156/268) dos animais abatidos e 92,31\% (12/13) dos municípios estudados estavam infectados pelo PCV-2. Mesmo apresentando resultados de prevalência inferiores aos encontrados em outros estados brasileiros e em outros países, o presente trabalho concluiu que é relevante a ocorrência do PCV-2 nos rebanhos mato-grossenses. Isto demonstra a importância de adotar medidas de controle mais eficazes para evitar que ocorra a Síndrome Multissistêmica do Definhamento dos Suínos (SMDS), e, com isso, amenizar o impacto econômico em sistemas de produção de suínos decorrente da mesma.
\end{abstract}

Descritores: circovírus, Mato Groso, suíno, PCR.

\begin{abstract}
In view of the absence of information about the prevalence of swine infected by the Porcine Circovirus type 2 (PCV-2) in Brazil and in the world, and the economic concern of these infections in the production of swine, this study aims to estimate the occurrence of PCV-2 in pigs slaughtered in the State of Mato Grosso, Brazil. For this, the Polimerase Chain Reaction (PCR) was performed in 121 strains of tonsils and 147 of lymph nodes from pigs slaughtered during january of 2006 and december of 2007. In all samples examined, 58.21\% (156/268) of slaughtered animals and $92.31 \%(12 / 13)$ of the cities studied were infected with PCV-2. Although this study shows a lower prevalence of PCV-2 infections, when compared to studies developed in other Brazilian states and other countries, it was concluded that the infection by this pathogen is relevant in swine herds of Mato Grosso. It demonstrates the importance of adopting effective control measures to avoid the occurrence of Postweaning Multisystemic Wasting Syndrome (PMWS) to decrease the economical impact of this disease in swine production.
\end{abstract}

Keywords: circovirus, Mato Grosso, swine, PCR. 


\section{INTRODUÇÃO}

A Síndrome Multissistêmica do Definhamento dos Suínos (SMDS) é uma enfermidade de grande importância econômica que está associada à infecção pelo Circovírus suíno tipo 2 (PCV-2) [6]. Essa síndrome é caracterizada clinicamente por apatia, dispneia, emagrecimento progressivo, aumento do volume dos linfonodos e, com a evolução da doença, aparecem sinais de icterícia, anemia, diarreia e outros sintomas relacionados a infecções secundárias [8]. Os achados microscópicos são caracterizados por infiltrados inflamatórios de células histiocitárias com intensidade variável, localizados em órgãos linfóides, fígado, rim e pulmão [16]. Observa-se também, uma marcada depleção linfóide e formação de células multinucleadas gigantes nos órgãos linfóides com presença de corpúsculos de inclusão intracitoplasmáticos basofílicos [9].

No Brasil, a SMDS foi diagnosticada pela primeira vez no ano 2000 [12], no entanto, através de estudos retrospectivos em órgão de suínos armazenados em blocos de parafina, verificou-se que a infecção de suínos por PCV-2 é datada de 1988 [8].

Atualmente, a SMDS é disseminada mundialmente e no Brasil há poucos dados disponíveis sobre a prevalência dessa síndrome, tanto em rebanhos como por região ou estado. Com isso, há dificuldade em avaliar o impacto econômico que possa causar ao setor produtivo e, consequentemente, prejudica a elaboração de justificativa para financiamento de estudos mais aprofundados para controle da doença [11]. Desta forma, o presente trabalho tem como objetivo estimar a ocorrência de infecção do Circovírus suíno tipo 2 em suínos abatidos no Estado do Mato Grosso.

\section{MATERIAIS E MÉTODOS}

Foram realizadas, entre o período de janeiro de 2006 a dezembro de 2007, coletas aleatórias de 147 amostras de linfonodos mesentéricos e 121 de tonsilas de suínos abatidos, provenientes de diversos municípios do Estado do Mato Grosso, onde cada amostra era provinda de animal diferente. A amostragem foi calculada pelo programa EPI-Info (1996), com os seguintes parâmetros: números de animais abatidos sob Inspeção Federal no estado (800.000 animais ano $^{-1}$ ); prevalência estimada de $40 \%$, intervalo de confiança de $95 \%$ e precisão absoluta de $10 \%$.

O material coletado foi encaminhado, sob refrigeração, ao Laboratório de Biologia Molecular da Universidade Federal do Mato Grosso, no qual foi extraído o DNA segundo [15]. A amplificação do DNA do PCV2 foi baseada na técnica descrita por [10] com iniciadores específicos para amplificar uma porção da ORF 2 (fase aberta de leitura 2) do PCV-2. Os primers utilizados foram: PCV2 SEM 5' - CAC GGA TAT TGT AGT CCT GGT - 3' e PCV2 ANT 5' - CCG TAC CTT CGG ATA TAC TGT - 3'. Os produtos de amplificação $(494 \mathrm{pb})$ foram fracionados através de eletroforese em gel de agarose $(1,0 \%)$ corados com brometo de etídeo e analisados em transluminador.

\section{RESULTADOS}

Os resultados obtidos no presente estudo estão demonstrados na Tabela 1. Ao avaliar conjuntamente as amostras, verificou-se que 58,21\% (156/268) dos animais estavam infectados pelo PCV-2. Observa-se também a presença da infecção deste agente em 92,31\% (12/13) dos municípios estudados. Já ao analisar amostras de linfonodos mesentéricos e tonsilas, observou-se que $44,22 \%(65 / 147)$ e $75,21 \%$ (91/121) foram positivas para PCV-2, respectivamente (Tabela 1).

\section{DISCUSSÃO}

Este estudo demonstra a ampla distribuição do PCV-2 nos principais polos produtivos de suínos de MT. Este fato é importante para programar medidas de controles e, com isso, diminuir ou até mesmo evitar a ocorrência da SMDS em rebanhos mato-grossenses.

Resultado superior ao presente trabalho foi encontrado na Espanha [14], no qual observou-se, através da técnica de Imunoperoxidase (IPMC) entre o período de 1885 a 1997 , que $72,7 \%$ (282/388) dos soros testados foram positivos. Ocorrência ainda maior foi observada em populações de suínos criados em fundo de quintal localizados em zonas rurais da Cidade do México [13], no qual obtiveram 92,24\% (642/696) e 98,14\% (106/108) de animais e rebanhos positivos sorologicamente para PCV-2, respectivamente. Com o emprego da técnica de ELISA, verificou-se soroprevalência menor $(40 \%)$ em rebanhos do município de Hangzhou (China) [18].

Em estudos sorológicos (IPMC) de rebanhos brasileiros, [3,4] observou-se que 95,41\% dos animais examinados nos estados de Santa Catarina (SC), Rio Grande do Sul (RS) e Minas Gerais (MG), e 96,6\% em $\mathrm{MG}$, foram positivos para PCV-2, respectivamente.

Ao estudar populações de Javalis (Sus scrofa scrofa), [2] observou-se, com auxílio da IPCM, que 
Tabela 1. Infecção de PCV-2 em linfonodos mesentéricos e tonsilas de suínos abatidos em municípios no Estado do Mato Grosso no período de janeiro/2006 a dezembro/2007.

\begin{tabular}{|c|c|c|c|c|}
\hline \multirow[b]{2}{*}{ Municípios } & \multicolumn{2}{|c|}{ Linfonodos Mesentéricos } & \multicolumn{2}{|c|}{ Tonsilas } \\
\hline & $\begin{array}{c}\text { Número } \\
\text { de amostras }\end{array}$ & $\begin{array}{c}\text { Amostras } \\
\text { positivas (\%) }\end{array}$ & $\begin{array}{c}\text { Número } \\
\text { de amostras }\end{array}$ & $\begin{array}{c}\text { Amostras } \\
\text { positivas (\%) }\end{array}$ \\
\hline Campo Verde & 10 & 70 & 4 & 50 \\
\hline Diamantino & 23 & 43,48 & $*$ & $*$ \\
\hline Itiquira & 12 & 75 & * & $*$ \\
\hline Jaciara & $*$ & $*$ & 1 & 100 \\
\hline Lucas do Rio Verde & 13 & 15,38 & $*$ & $*$ \\
\hline Nova Mutum & $*$ & $*$ & 20 & 90 \\
\hline Pedra Preta & $*$ & $*$ & 26 & 80,77 \\
\hline Poconé & $*$ & $*$ & 2 & 0 \\
\hline Poxoréu & 18 & 61,11 & $*$ & $*$ \\
\hline Santo Antônio do Lerveger & 1 & 100 & 3 & 0 \\
\hline Sinop & 47 & 31,91 & 50 & 80 \\
\hline Sorriso & 6 & 16,67 & 8 & 75 \\
\hline Tapurah & $*$ & $*$ & 2 & 100 \\
\hline Total & 147 & 44,22 & 121 & 75,21 \\
\hline
\end{tabular}

*Não há amostra

$84,9 \%$ dos animais foram soropositivos para PCV-2 nos estados de São Paulo, Paraná, RS, SC e MG. Este resultado mostra alta prevalência do PCV-2 nessa espécie, que, em condições de manejo inadequadas, realizadas na criação intensiva desses animais, permitem a manutenção e circulação do agente de forma semelhante às condições encontradas nas granjas de suínos.

Os resultados de infecção de suínos por PCV-2 em MT foram inferiores aos encontrados por outros estudos. Isto pode ser explicado pela baixa densidade de animal, 0,8 suínos por $\mathrm{km}^{2}$ e o bom nível sanitário nesse estado [1].

É importante ressaltar que a técnica de diagnóstico utilizada neste trabalho foi o PCR, pois exames sorológicos indicam apenas que o animal em algum momento de sua vida teve contato com o vírus, podendo haver assim uma prevalência alta de anticorpos contra PCV-2 [5]. Já a técnica de PCR indica que o animal está infectado pelo agente pesquisado no momento em que se realizou a coleta da amostra para o referido exame [5].

Entretanto, o fato de o animal estar infectado com o PCV-2 não indica que este esteja com a SMDS. Então, para que se tenha um diagnóstico desta enfermidade, são necessários que haja as manifestações clínicas características da doença, lesões microscópicas características e a identificação do PCV-2 nessas lesões [17].

Já foi comprovada a presença do DNA do PVC-2 em sêmen de reprodutores suínos, sugerindo que o macho infectado representa um fator importante na disseminação do PCV-2 dentro do plantel e entre rebanhos [7]. Esse fato pode ser uma explicação para a disseminação mundial do vírus em rebanhos de suínos.

\section{CONCLUSÕES}

Embora os resultados encontrados no presente trabalho sejam inferiores aos relatados em outros estados, verificou-se que é relevante a ocorrência do PCV-2 no estado do Mato Grosso, justificando assim a necessidade de se realizar mais estudos com finalidade de se conhecer a epidemiologia e patogenia da SMDS e, com isso, adotar medidas de controle mais eficazes para evitá-la, amenizando, dessa forma, o impacto econômico em sistemas de produção de suínos.

Agradecimentos. À Fundação de Amparo à Pesquisa do Estado do Mato Grosso (FAPEMAT) pelo financiamento desta pesquisa. 


\section{REFERÊNCIAS}

1 ACRISMAT. 2008. Histórico - Disponível em: http://www.acrismat.com.br/acrismat.asp?ntipo=Histórico\&tipo=historico. Acessado em maio 2008.

2 Barbosa C.N., Lobato Z.I.P., Nakajima M., Ciacci-Zanell J.R. \& Thomaz M.M. 2005. Prevalência do Circovírus suíno Tipo 2 (CVS-2) em javalis (Sus scrofa scrofa) In: Resumo do XII Congresso brasileiro de veterinários especialistas em suinos (Fortaleza, Brasil). pp.99-100.

3 Barbosa C.N., Lobato Z.I.P., Nascimento E.F. \& Cavalcanti J.E. 2005. Estudo do perfil sorológico para o Circovirus suíno Tipo 2 (CVS-2) em granjas tecnificadas para a produção comercial de suínos. In: Resumo do XII Congresso brasileiro de veterinários especialistas em suínos (Fortaleza, Brasil). pp.97-98.

4 Barbosa C.N., Lobato Z.I.P., Nascimento E.F., Nakajima M., Ristow L.E. \& Cavalcanti J.E. 2005. Distribuição de anticorpos para o Circovirus suínos Tipo 2 (CVS-2) em granjas comerciais de suínos no estado de Minas Gerais. In: Resumo do XII Congresso brasileiro de veterinários especialistas em suínos (Fortaleza, Brasil). pp.101-102.

5 Barcellos D.E.S.N., Sobestiansky J., Moreno A.M., Pùrto R.N.G. \& Souza M.A. 2005. Utilização do diagnóstico laboratorial. In: Sobestiansky J., Barcellos D. E.S.N., Moreno A.M., Sobestiansky A. \& Poleze E. (Eds). Suínos: Coleta e remessa de material para laboratórios para fins de diagnóstico. Goiânia: Art 3, pp.13-41.

6 Castro A.M.M.G., Cortez A., Heinemann M.B., Brandão P. \& Richtzenhain L.J. 2007. Circovírus suíno tipo 2 (PCV-2). Arquivos do Instituto Biológico, São Paulo. 74(3): 281-291.

7 Ciacci-Zanella J.R., Gava D., Gava A., Felicio,R.P., Mores N. \& Oliveira S.R. 2006. Análises do Sêmen de Suínos em Centrais de Inseminação Artificial e Detecção de Circovírus suíno Tipo 2 (PCV-2). Embrapa-CNPSA. Concórdia, SC. (Comunicado Técnico, 438). 4p.

8 Ciacci-Zanella J.R., Morés N., Simon N.L., Oliveira S.R. \& Gava D. 2006. Identificação do Circovírus suíno Tipo 2 por reação em cadeia da polimerase e por Imunoistoquímica em tecidos suínos arquivados desde 1988 no Brasil. Ciência Rural. 36(5): 1480-1485.

9 Dupont K., Nielsen E.O., Bakbo P. \& Larsen L.E. 2008. Genomic analysis of PCV-2 isolates from Danish archives and a current PMWS case-control study supports a shift in genotypes with time. Veterinary Microbiology. 128(1-2): 56-64.

10 Fenaux M., Halbur P.G., Gill M., Toth T.E. \& Meng X.J. 2000. Genetic characterization of type 2 porcine circovirus (PCV-2) from pigs with postweaning multisystemic wasting syndrome in different geographic regions of North America and development of a differential PCR-restriction fragment length polymorphism assay to detect and differentiate between infections with PCV-1 and PCV-2. Journal of Clinical.Microbiology. 38(7): 2494-2503.

11 Mores N. 2005. Impacto econômico da circovirose na produção de suínos. In: Resumo do IV Seminário Internacional de Aves e Suínos - Avesui 2005. Suinocultura: Saúde e Meio Ambiente. v.5. (Florianópolis, Brasil). pp.9-13.

12 Mores N., Ciacci-zanella J.R., Amaral A.L., Coldebela A., Lima G.J.M.M., Zanella E., Lima E.S., Rangel L.F.S., Zancanaro M. \& Gava D. 2007. Prevenção da Circovirose Suína pelo uso do Plasma Suíno Ultrafiltrado Produzido por "Spray Dried". Concórdia, SC, Embrapa - CNPSA. 6p. (Comunicado Técnico, 456).

13 Ramírez-Mendoza H., Martínez C., Mercado C., Castillo-Juárez H., Hernández H. \& Segalés J. 2007. Porcine circovirus type 2 antibody detection in backyard pigs from Mexico City. Research in Veterinary Science. 83(1): 130-132.

14 Rodriguez-Arrioja G.M., Segales J., Rosell C., Rovira A., Pujols J., Plana-Dran J. \& Domingo M. 2003. Retrospective study on porcine circovirus type 2 infection in pigs from 1985 to 1997 in Spain. Journal of Veterinary Medicine B. 50(2): 99-101.

15 Sambrook J. \& Russell D.W. 2001. Extraction of bacteriophage $\lambda$ DNA from large-scale cultures using proteinase k and SDS. In: Molecular coloning: a laboratory manual. 3rd. edn. v.1. New York: Cold spring Habor Laboratory Press, pp.2.56-2.60.

16 Sobestiansky J., Barbarino Jr. P., Seyboth L. \& Matos M. 2002. Circovirose suína e circovírus suíno. In: Sanidade em Foco. Goiânia, GO. 52p.

17 Sorden S.D. 2000. Update on porcine circovirus and postweaning multisystemic wasting syndrome (PMWS). Swine Health and Production. 8(3): 133-136.

18 Yang Z., Shuai J., Dai X. \& Fang W. 2008. A survey on porcine circovirus type 2 infection and phylogenetic analysis of its ORF2 gene in Hangzhou, Zhejiang Province, China. Journal of Zhejiang University Science B. 9(2): 148-153. 